\title{
体位変換における鼻アレルギー患者の鼻呼吸抵抗の変化
}

\author{
東邦大学大橋病院耳鼻咽喉科学研究室 \\ 高木芳夫, 加藤明理, 堀井恵子, 武安陽子 \\ 臼井信 郎

\section{NASAL RESPIRATORY RESISTANCE OF NASAL ALLERGIC PATIENTS IN POSTUAL CHANGE}

\author{
YOSHIO TAKAGI, M.D., MERI KATO, M.D., KEIKO HORII M.D., \\ YOUKO TAKEYASU, M.D. and NOBUO USUI, M.D.
}

Department of Otorhinolaryngology Ohashi Hospital, Toho University School of Medicine, Takyo

Oscillation rhinomanometry was used to measure nasal respiratory resistance during postual change in normal individuals, and in patients with allergic rhinitis.

1. The response curve in the nasal respiratory resistance during postual change was classified into three types by patterns as follows. 1) Type I (Horizontal type) where the nasal respiratory resistance unchanges from the original line. 2) Type Il (Incremental type) where the nasal respiratory resistance increases with the lapse of time. 3) Type III (Mountain and mountainvalley type) where the nasal respiratory resistance responds for a certain period but gradually returns to the original state or repeats Mountain type.

2. Many patients with allergic rhinitis showed a tendency to indicate Type III. But many normal individuals showed a tendency to indicate Type I. The tendency of allergic rhinitis was pronounced by methacholine inhalation, but the tendency was diminished by adrenalin inhalation.

Key words : 体位変換, 鼻アレルギー, 鼻呼吸抵抗, 自律神経

A $91-1825-32822$

はじめに

鼻閉は，アレルギー性鼻炎等鼻疾患の主症状の一つ であり、この鼻閉が仰卧によって増強大することはよ く知られており報告もされている によって鼻閉が改善されることが報告されている2゙. また，鼻アレルギ一の発症には，免疫学的要因のみな らず，自律神経系の祭張状態あるいは弛緩状態が重要 な役割が演じていることが報告されている゙!。

今回，著者らは，この鼻粘膜の自律神経調節機構を 調べる目的で，体位変換が鼻腔通気にいかなる影響を 及ほすかを鼻呼吸抵抗によって測定し検討した。

対象と方法

(1) 対象
対象症例は，当科外来を受診した八ウスダスト鼻ア レルギ一患者34例，健常者31例の計65例である．年䶗 は12歳から74歳, 平均年路32.6歳, 平均身長 $162.8 \mathrm{~cm}$, 男子 40 人，女子 25 人であった。鼻アレルギーの診断は 奥田の診断基淮 に従い，2項目以上陽性のものを悬 アレルギーと診断した。また，奥田の患者重症度判定 基準" に従って重症度中等度以上の患者を対象とし た。なお，対象選択にあたり，鼻閉の原因となる鼻咠， 鼻中隔弯曲症等の形態異常および中等症以上の鼻副鼻 㕵炎を合併する症例は除外した。

(2) 鼻と呼吸抵抗の測定方法

鼻とロからの呼吸抵抗の測定はチエスト社製回転鼻 腔通気度測定装置 (写真 1 ) を用いて, $3 \mathrm{~Hz}$ オッジ ーション法により連続的に測定した。同装置は, 電動 


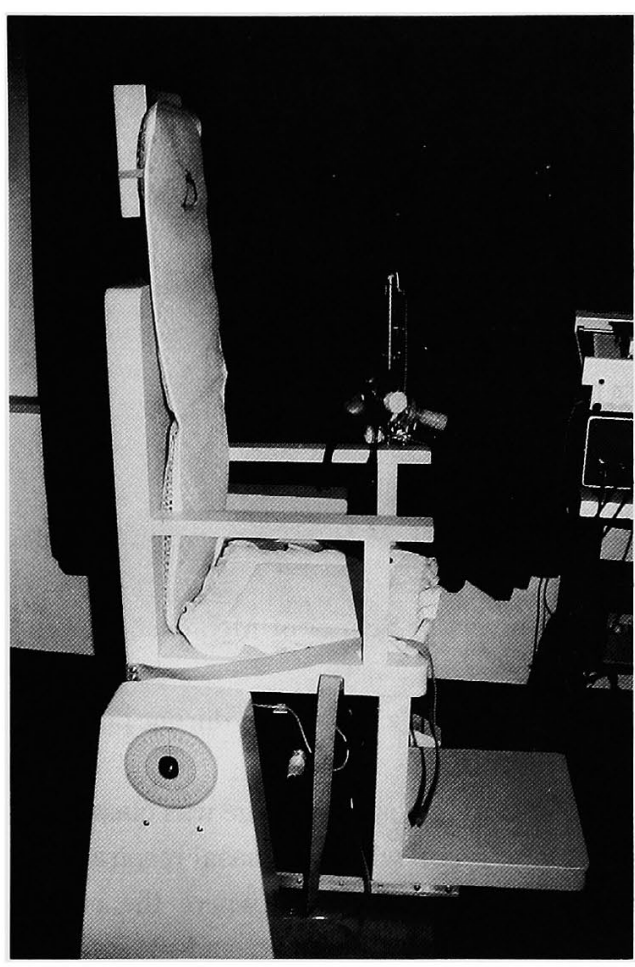

写真 1

モーターにて椅子が5度/秒の等角速度で垂直から水平 まで 90 度回転するようになっている(写真 2 )。被検者 は回転椅子に着席し，先端に熱線式流量計を装着した 顔面マスク (Rudolph facemask 7900型 Hans Rudolph, Inc.) を顔面に密着させへッドバンドにて固
定して，まず，口を閉じ鼻呼吸の状態にて安静呼吸を 行わせた後, 椅子を回転させ 1 分間連続的に鼻呼吸抵 抗を測定し,体位変換時の反応パターンについてみた。 続いて，口呼吸抵抗の測定はシンクロナイズドスイミ ング用のノーズクリップを被検者に装着させ, 口呼吸 の状態にして顔面マスクを通して鼻呼吸抵抗測定時と 同様に測定した。

(3) メサコリン投与方法

詹 $^{5)}$ の方法に従って，アストグラフ に碩面マスク を装着し，メサコリンを負荷した。すなわち，体位変 換による鼻呼吸抵抗を測定した後，アストグラフを用 いて安静鼻呼吸を行わせながら, 生理食塩水に溶解し た 0. 047〜 25mg/ml にまでの10段階の濃度のメサコ リンを 1 分間毎に10分間バポネフリンネプライザーで エアロゾル化して負荷した．メサコリン負荷終了後再 び体位変換による鼻呼吸抵抗の変化を測定した。

\section{(4)アドレナリン投与方法}

メサコリン負荷と同様アストグラブ6) を用いて，生 理食塩水に溶解した 6.25〜 $1000 \mu \mathrm{g} / \mathrm{ml}$ までの 6 段階 の濃度のアドレナリンを, 安静鼻呼吸を行わせながら 1 分毎に11分間鼻腔へ負荷し, 負荷前後で体位変換に よる鼻呼吸抵抗の変化を測定した. $1000 \mu \mathrm{g} / \mathrm{ml}$ のアド レナリンを 1 分間吸入した場合を 1 unitとした（図 1 ).

\section{結 果}

（1）反応パターンの分類

体位変換による鼻と口呼吸抵抗の反応パターンは,

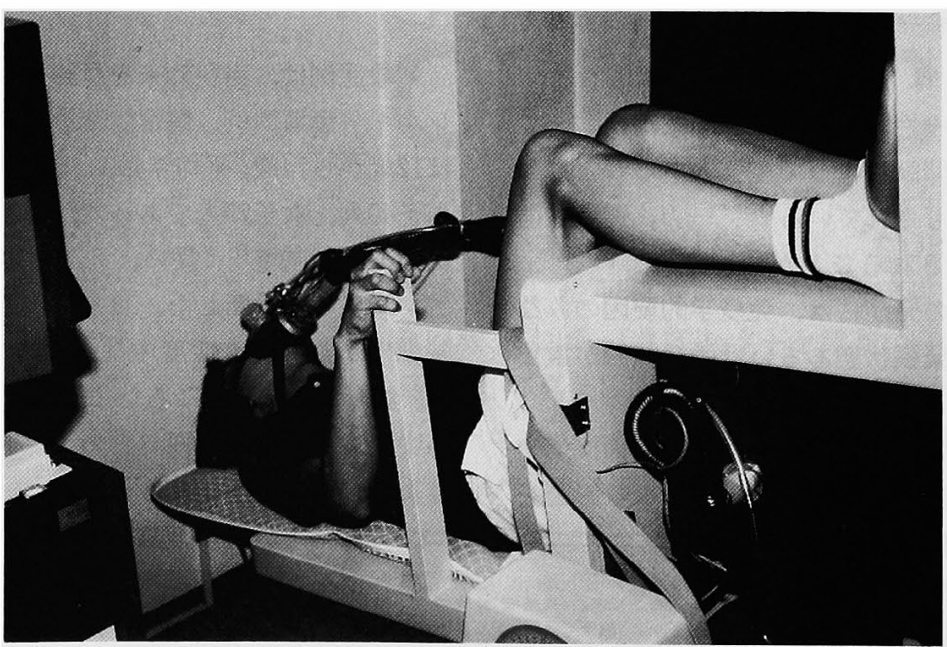

写真 2 


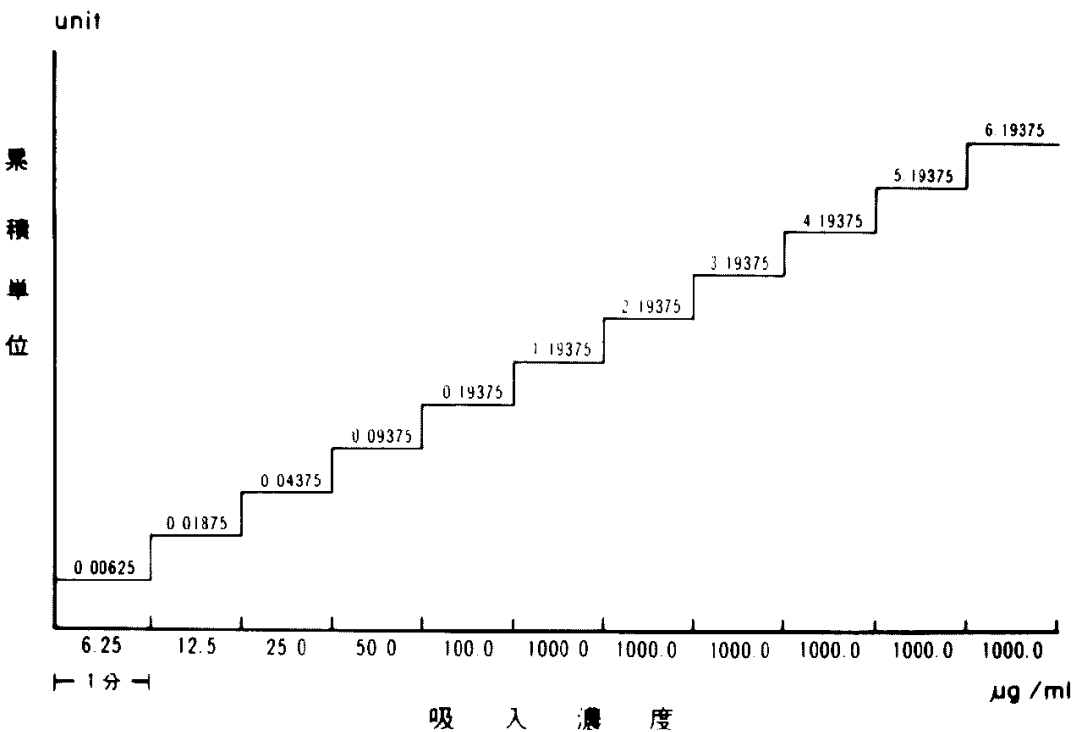

図1アアドレナリン投与量
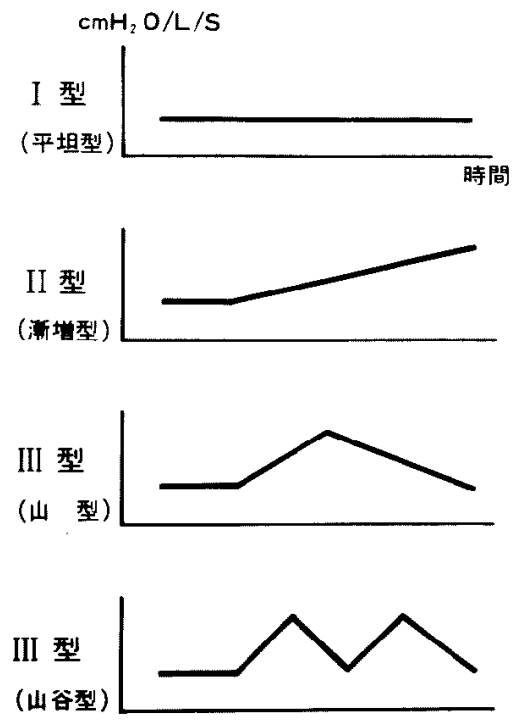

図 2 反応パターン分類

鼻から呼吸した場合も，口から呼吸した場合も同様の パターンを示した。すなわち，体位変擙中ほとんど抵 抗の上昇の認められない平坦型，時間経過とともに漸 堌性の抵抗の上昇が認められる漸増型，時間経過の途 中において増加した抵抗が減少する山型および一度減 少した抵抗が再び増加する山谷型に分類できた（図 2). 平坦型をI 型, 漸増型をII 型, 山谷型を含む山型 を型とした。
表 1 鼻呼吸抵抗反応パターン

\begin{tabular}{|c|c|c|c|}
\hline & 鼻アレルギー & 煡 & 常 \\
\hline $\mathrm{I}$ & 7 & & 18 \\
\hline II & 4 & & 8 \\
\hline III & 23 & & 5 \\
\hline 計 & 34 & & 31 \\
\hline
\end{tabular}

表 2 口呼吸抵抗反応パターン

\begin{tabular}{|c|c|c|c|}
\hline & 鼻アレルギー & 健 常 & 者 \\
\hline $\mathrm{I}$ & 12 & 21 & \\
\hline II & 8 & 8 & \\
\hline III & 14 & 2 & \\
\hline 計 & 34 & 31 & \\
\hline
\end{tabular}

（2）鼻呼吸抵抗反応パターンの検討

被検者を鼾呼吸の状態にして, 各群における章呼吸 抵抗反忘パターンについて検討した（表 1)。鼾アレル ギ一患者では，I 型 ( 7 例)，II型 ( 4 例)，III型 (23 例)，健常者では，I 型(18例)，II型(8例)，III型( 5 例) と，鼻アレルギー患者ではIII型，健常者ではI 型 を示す例が多かった。

(3) 口呼吸抵抗反応パターンの蚞討

被検者をノーズタリップを用いて呼吸の状態にし 


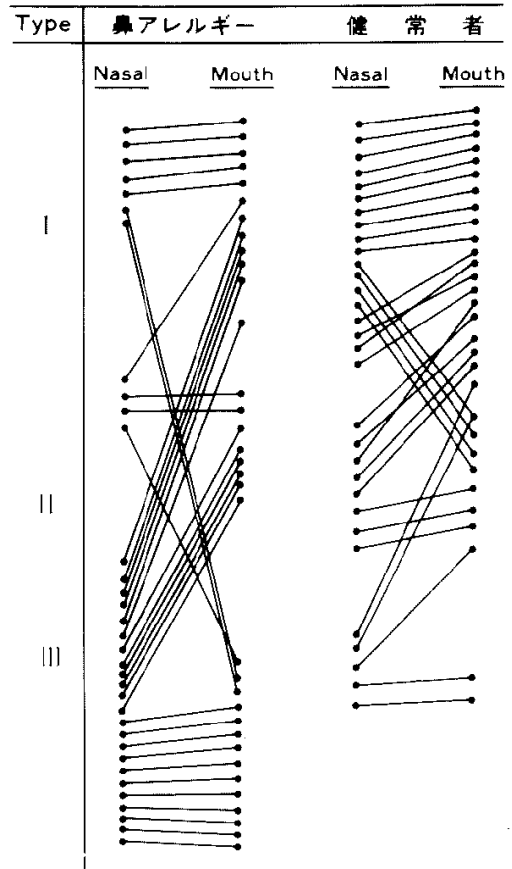

図 3 反応パターンの変化

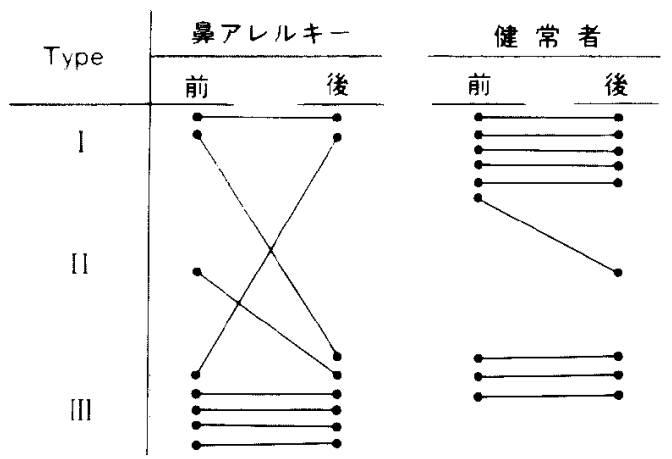

図 4 メサコリン負荷後の鼻呼吸反応パターン

て，各群に抢ける口呼吸抵抗反応パターンについて検 討した（表 2$)$ ．㐭アレルギー患者で注，I型 (12例)， II 型 ( 8 例)，III型 (14例)，健常者では I 型 (21例)， II型 ( 8 例)，III型（2 例）と鼻アレルギ一患者では特 にパターン別にみてどの型が多いといった傾问は認め られなかったが, 健常者ではI型を示す例が多かった。

(4) 鼻と口呼吸時の反応パターンの変化

各症例に扔ける鼻呼吸時扔よび口呼吸時の反応パタ ーンについてみると（図 3)，鼻アレルギー患者におい て鼻呼吸でIII型を示した33例のうち呼吸においても II型を示した症例は11例であり，他の22例は口呼吸に

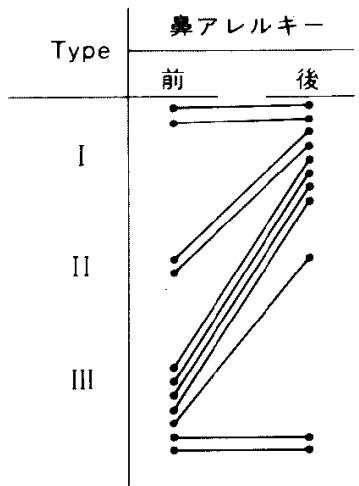

保常者

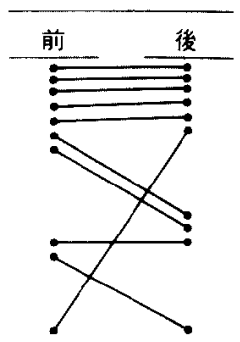

図 5 アドレナリン負荷後の鼻呼吸反応パターン

おいてはI型およびI型を示した。一方，健常者では 顕著な変化の傾向は認められなかった。

（5）メサコリン鼻腔負荷

罟アレルギ一患者 8 例, 健常者 9 例についてメサコ リン負荷前後の鼻呼吸抵抗反応パターンの変化をみる と（図 4)，鼻アレルギー患者では負荷前にIII型を示し た 5 例のうち，負荷後にもIII型を示したものは 4 例て あり，I，II型を負荷前に示した各 1 例も，負荷後に はIII型を示し，鼻アレルギー患者に抢いてはメサコリ ン鼻腔負荷によりIII型を示す傾向がみられた。

(6) アドレナリン鼻腔負荷

鼻アレルギー患者11例, 健常者10例についてアドレ ナリン鼻腔負荷前後の鼻呼吸抵抗反応パターンの変化 をみると(図 5), 鼻アレルギ一患者では負荷前にIII型 を示した 7 例のうちアアドレナリン負荷後にIII型を示 すもの 2 例のみで他の 5 例は，II型 1 例，I 型 4 例 とI 型を示す傾向にあった。一方，健常者では顕著な 傾向は認められなかった。

\section{考察}

鼻閉怄，鼻アレルギー等鼻疾患の主症状の一つであ る.この鼻閉は仰卧位によって増強することはよく知 られて㧍り，側臥位にて同側の鼻閉が起こることが報 告されている゙1.

Rundcarn $t z^{7 / 8)}$ は水平より20度以下の卧位にすると 健常者では鼻呼吸抵抗は少ししか上昇しないが，鼻炎 の患者では上昇率が大であることを報告しており，こ の現象を“positive posture reaction”と呼んでいる。 また，長谷川ら も頭位を水平に近づけるに従い健常 者に比べ鼻アレルギ一患者において鼻腔抵抗が増大す ることを報告している。今回の著者らの結果では，健 
常者, 鼻アレルギー患者とも鼻呼吸抵抗の上昇を認め る症例があったが(表 1)，その抵抗の上昇はバラッキ が大きく，両群の間に差は認められなかったため，体 位変換負荷による呼吸抵抗の変化を反応パターンとし て検討した.

体位変換による反応パターンは，体位変換中ほとん ど抵抗の上昇の諗められない平坦型, 時間経過ととも に漸増性に抵抗の上昇が認められる㳿増型, 時間経過 の途中において增加した抵抗が隇少する山型，および 一度减少した抵抗が再び増加する山谷型に分類できた (図 2 ). 平坦型を I 型, 漸增型をII 型, 山谷型を含む 山型をIII型とした。

被検者を鼻呼吸の状態にした時の鼻呼吸抵抗反応パ ターンについてみると鼻アレルギー患者ではIII型，健 常者ではI型を示す傾向にあった（表 1)。一方, 被検 者にノーズクリップを用いてロ呼吸の状態にした時の 口呼吸抵抗の反応パターンについてみると, 鼻アレル ギー患者では特に傾向は認めら机なかったが，健常者 ではI 型を示す傾向にあった(表 2)。また，鼻呼吸時 および口呼吸の反応パターンの変化について各症例ご とに検討すると(図 3), 鼻アレルギー患者において鼻 呼吸でII型を示した33例のうち，口呼吸においてもIII 型を示した症例は11例であり，他の22例は口呼吸にお いてはI型およびII型を示した，健常者では顕著な傾 向は認められなかった。これらのことにより，鼻アレ ルギー患者の体位変換に上る鼻呼吸抵抗反応パターン は，III型を示す傾向が顕著であると考えられたが，し かし，III型は山型および山谷型の 2 型を含むため, 今 後さらに検討する必要があると思われる。

Rundcrant $z^{8)}$ は, positive posture reaction $の$ 成因 を，頸静脈の圧迫によっても起こることから hydrostatic venous pressure の増加に抵抗できない粘膜血管 の hypotonicity に基づくものとして，鼻炎（アレルギ 一性鼻炎および感染性鼻炎)の鼻粘膜血管の hypotonicity を指摘している。また，鼻アレルギーに おいては副交感神経系は優位にあり，この副交感神経 系の優位性は muscarinic receptor の增加に基づくと

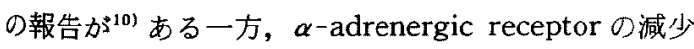
や鼻粘膜中のノルアドレナリン含量の滅少"11による 交感神経の弛緩に基づく, 副交感神経系の優位性が報 告されている，そこで，体位変換による鼻呼吸抵抗反 応パターンに対する自律神経系の関与を知るため, メ サコリンまたはアドレナリンを鼻呼吸によって鼻粘膜 に負荷し，その前後に招ける鼻呼吸抵抗反応パターン
について検討した（図 4，5）.

メサコリン負荷前後の反応パターンの変化について みると，鼻アレルギー患者に多く認められたIII型 5 例 のうち，メサコリン負荷後にもIII型を示したものは 4 例であり，I 型，II型を負荷前に示した各 1 例も，負 荷後にはIII型を示したが，健常者においてて影著な傾 向は認められなかった。一方，アドレナリン負荷前後 の反応パターンについてみると，鼻アレルギ一患者に 多く認められるIII型 7 例のうち，アドレナリン負荷後 にIII型を示すものは 2 例のみで他の 5 例は, II 型 1 例, I 型 4 例と I 型を示す傾问にあったが，健常者では顕 著な傾向は認められなかった，鼻アレルギー患者の体 位変換による鼻呼吸抵抗反応パターンにおいてはIII型 を示す傾向が顕著であるが，副交感神経の agonist で

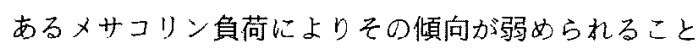
は, 鼻アレルギー患者の示すIII型に自律神経系が密接 に関与していることを示唆すると考えられる。

コリン作動神経は鼻腺の周团，動脈，小動脈の周囲 に存在して拈り、アドレナリン作動神経は主に動脈の 周囲にあり，鼻腺の周囲には少ないことが報告 ${ }^{12113)}$ れている。すなわち，脈管系はアドレナリン，コリン 両支配であり，鼻腺はコリン支配が優位と考えら机る ことから，鼻呼吸抵抗の反応パターンの成因に，鼻粘 膜の脈管系が深く関与していると考元られた。しかも， 副交感神経の agonist であるメサコリンによって鼻ア レルギー患者の特徵が顕著となり，アドレナリン負荷 によってその特徴が弱められることは，鼻アレルギー 患者では副交感神経系が優位になっていることを示唆 して扔りこのことは，Rundcrant $z^{8)}$ が述べている positive posture reactionの成因にかか子和る鼻粘膜血 管の hypotonicity に関連する可能性があると考元ら れた。また，Rundcrantz ${ }^{8)}$ はアレルギー性鼻炎が改善 されるにつれ，体位変換による鼻呼吸抵抗の変化が改 善すると報告して抢り，長谷川ら は具体的にBeclomethasone dipropionate nasal spray の使用によ り頭位によるアレルギー性鼻炎の鼻慙抵抗の変化が改 善されると報告している，今後さらに，アレルギー性 鼻炎の治療薬の体位変換に上る鼻呼吸抵抗の反応パ ーンに及ぽす効果について検討を要するものと考えら れた。

\section{まとめ}

鼻粘膜の自律神経調節機構を調べる目的で体位変換 が鼻腔通気にいかなる影響を及潘すかをオッシレーシ 
ヨン法による回転鼻腔通気度装置によって検討した。

1) 体位変換による反応曲線のパターンは，I型(平 坦型)，II 型 (漸増型)，III型（山型および山谷型）の 3 型に分類できた。

2）䁷アレルギー患者の鼻呼吸抵抗反応パターンは III型を，健常者では I 型を示す傾向にあった.

3）舅アレルギー患者のIII型を示す傾向はメサコリ ン負荷により増強されたが，しかしアドレナリン負荷 によって減弱された。

\section{文献}

1) Heetderlas D: Observations on the reaction of normal nasal mucous membrane. Amer J Med Su 174: 231, 1927.

2) Forsyth RD, Cole P, RJ Shephard: Exercise and nasal patency. J Appl physiol 55: 860-865, 1983.

3）渡瀬隆雄：鼻アレルギ一鼻粘膜に対する自律神経作動 性薬剤の影饗。耳鼻臨床78：1983-1990，1985。

4）奥田 稔：重アレルギ一診療の実際。金原出版, 東京, 1971.

5）詹 光漢：メサコリン連続吸入による鼻過敏性試験. 耳展28：135-142,1985.

6）滝島任, 飛田涉, 鈴木俊介, 佐々木孝夫：気道過敏 性検出のための新しい試み。日本医事新報2797：30$34,1977$.

7) Rundcrantz H : Posture and congestion of nasal moucosa in allergic rhinitis. Acta Otolaryngol 58:
283-287, 1964.

8) Rundcrantz $\mathrm{H}$ : Postual variations of nasal patency. Acta Otolaryngol 68: 435-443, 1969.

9）長谷川誠, 斎藤洋三: Beclomethasone dipropionate nasal sprayのアレルギー性舅炎に扔ける頭位性鼻腔 抵抗変化比抒よほす影響. 耳鼻臨床71：1125-1131， 1978.

10）石部司, 奥野吉昭, 山下敏夫, 熊沢忠躬, 久野高義 他: 厽アレルギーにおける自律神経受容体の動態.日耳鼻 $85: 1618,1982$.

11）藤谷哲造, 金谷けい子, 井上健造, 高原哲夫, 溝尻源太 郎他：舅アレルギー患者の下甲介組織中のノルエピ ネフリン含有量についての研究. 日耳䁂84：169-173， 1981.

12）石井暂夫, 山田 修：鼻粘膜に书ける自律神経終末の 微細構造.耳䁷臨床68：599-608，1975.

13) Nomura $Y$ and Matsuura $T$ : Distribution and clinical significance of the autonomic nervous system in the human nasal mucosa. Acta Otolaryngol 73: 493-501, 1972.

本論文の要旨は第 4 回日本耳鼻咽喉科免疫アレルギー研 究会，第24，25回日本鼻科学会において発表した。

（原稿受付 昭和63.1.8日）

別刷請求先 $干 153$ 東京都目黑区大橋 2-17-6 東邦大学医学部付属大橋病院耳舅咽喉科 高木芳夫 